\title{
Evidence about the value of financial statement audit in the public sector
}

\author{
David Hay $^{\mathrm{a}}$ and Carolyn J. Cordery ${ }^{\mathrm{b} *}$
}

a Department of Accounting and Finance, The University of Auckland Business School, University of Auckland, 12 Grafton Road, Auckland, New Zealand. Email: d.hay@auckland.ac.nz.

${ }^{* b}$ Accounting Department, Aston Business School, Aston University, Aston Triangle, Birmingham, B4 7ET United Kingdom. Email: c.cordery@aston.ac.uk.

David Hay is the Professor of Auditing at the University of Auckland, New Zealand. David is actively involved in auditing research, teaching and professional activities. He won the 2017 "Notable Contribution to the Auditing Literature Award" presented by the Auditing Section of the American Accounting Association, with his co-authors, is also co-author of The Routledge Companion to Auditing, and an author of about 50 articles in refereed journals, books and book chapters. David has a substantial role in the publication of auditing research as the Editor-in-Chief of the International Journal of Auditing and serves as an editorial board member of many other research journals.

Carolyn Cordery is a Professor of Charity Accounting and Accountability at Aston University, UK and holds a fractional appointment at Victoria University in Wellington, New Zealand. Her research focuses on not for profit organisations' accounting and accountability, including charities and sports clubs being interested in how these organisations are resourced and the resource constraints that cause many of these organisations to be financially vulnerable. Carolyn is Associate Editor of Accounting History and British Accounting Review and on other editorial boards. She has been actively involved in accounting standard setting and is a Fellow of Chartered Accountants Australia, New Zealand and CPA Australia. 


\title{
Evidence about the value of financial statement audit in the public sector
}

\author{
Abstract: \\ Multiple, complementary explanations have been developed to explain audit demand. \\ Substantial evidence exists for these explanations in the private sector, but they have been \\ explored to a lesser extent in the public sector. We assess the extent to which these \\ explanations for the value of auditing are relevant in the public sector by examining evidence \\ from New Zealand. We find the use of overlapping explanations helps to explain how \\ auditing is valuable to a wide variety of users.
}

\section{Impact}

This paper uses empirical evidence to examine the private sector explanations for audit in the public sector setting. It argues that attention to these arguments can assist Supreme Audit Institutions (SAIs) in articulating how public sector audits can demonstrate their ongoing relevance to citizens, Parliament and other stakeholders, as required by the applicable international standards. 


\section{Evidence about the value of financial statement audit in the public sector}

\section{Introduction}

There is growing interest in the value of public sector audit, especially in respect of performance audits (Barrett, 2012; Talbot \& Wiggan, 2010), but Bonollo (2019) highlights that the value of financial statement audits in this setting is under-researched, and it tends to be under-theorised. There is also a geographical and methodological divide between public sector auditing research and the larger body of research in the private sector (Goddard, 2010, p. 76; Hay \& Cordery, 2018, p. 2), whereby much public sector auditing research does not make reference to the more well-established explanations for the value of auditing. Yet public sector and private sector auditing are similar enough that it is worth investigating to what extent the more widely used private sector explanations are relevant and therefore could be used to undertake a broader range of discussions of public sector audit. The public sector provides auditing researchers with an opportunity to test their understanding of the reasons for auditing and the ways it achieves value. The objective of this research is to assess to what extent stakeholders perceive value in public sector financial statement auditing and examine private sector explanations in this regard. The explanations examined are the agency explanation; signalling; insurance; management control; governance; and the confirmation hypothesis. We demonstrate to what extent the explanations are relevant to public sector stakeholders. We use evidence from stakeholders in New Zealand. This jurisdiction is an example with relevance to many others with similar public sector audit institutions. The paper argues that attention to audit explanations can assist Supreme Audit Institutions (SAIs) in articulating how public sector audits can demonstrate their ongoing relevance to citizens, Parliament and other stakeholders.

The value of audit is a very relevant issue to SAIs. Most SAIs (including New Zealand's) have agreed to follow the International Standards for Supreme Audit Institutions (ISSAIs). One of the standards, ISSAI 12 (International Organization of Supreme Audit Institutions, 2013), explains that public sector auditing makes a difference to the lives of citizens; that an independent, effective and credible SAI is an essential component in a democratic system; and that SAIs have a responsibility to demonstrate their ongoing relevance to citizens, Parliament and other stakeholders. 
Auditing in the New Zealand public sector is organised under the Westminster system and therefore is conducted under the direction of the Controller and Auditor-General, who is the head of the SAI, the Office of the Auditor-General (OAG). The authors were invited to conduct this research to help meet the goal to assess the extent to which the OAG as an SAI was relevant to stakeholders ${ }^{1}$. New Zealand is known for public sector innovations, and was a leader in the adoption of New Public Management (NPM) (Grossi et al., 2009; Pallot, 2003).

This paper explores explanations that are used widely in auditing research but have not yet been widely applied in the public sector. Our contribution is finding that public audit is valuable to a wide range of stakeholders in different ways, in accordance with several of the explanations for the value of auditing, but not all. We also make recommendations about potential changes to audit practice. We now turn to the explanations of the demand for auditing. Our research method is explained along with the context, and the findings presented, before conclusions made along with recommendations for practice and further research.

\section{Explanations of the demand for auditing}

To assess the value of auditing in the public sector, we examined previous auditing literature and summarised explanations for auditing from previous research (Hay \& Cordery, 2018). Here we review these explanations and the extent of relevant evidence, as summarised in columns (2) to (4) of Table 1.

\section{INSERT TABLE 1}

Agency: One way in which auditing is valuable is by reducing agency costs to facilitate monitoring and bonding. Where one party, the principal, delegates authority to the agent, then the agent might be self-interested and spend money for their own benefit; or might shirk; or might be misguided (Wallace, 1987). If nothing is done to avoid these risks, then the principal will spend less; or will avoid entering into the transactions altogether. Agency costs include those that arise when otherwise useful activities are not undertaken because the risks are too high that the self-interested agent will take advantage of the situation; or when the principal expends effort in overseeing the agent. An agent might appoint an auditor in order to give the principal more confidence, reducing these agency costs (Chow, 1982). There is historical evidence that audits were arranged voluntarily in this way in some settings (Chow, 1982;

\footnotetext{
1 The outputs of the full study include less theoretical development. See: https://www.victoria.ac.nz/sacl/centres-and-chairs/cagtr/occasional-papers
} 
Wallace, 1980). Agency theory has been used to explain issues related to financial reporting and auditing in previous public sector studies (e.g., Baber, 1983; Bradbury \& Scott, 2015; Ingram, 1984; Jensen \& Payne, 2005; Zimmerman, 1977). Agency relationships in the public sector are more complex than in the private sector as there are several levels of relationship (Streim, 1994). Moe (1984, p. 765) states that:

\section{Democratic politics are easily viewed in principal-agent terms. Citizens are principals, politicians are their agents. Politicians are principals, bureaucrats are their agents. The whole of politics is therefore structured by a chain of principal- agent relationships, from citizen to politician to bureaucratic subordinate and on down the hierarchy to the lowest-level bureaucrats.}

As a result, in the public sector there are more agency relationships than in private sector settings, and therefore a wider variety of reasons why auditing could be important. Citizens might need to hold politicians to account; politicians in Parliament to oversee the government; and government Ministers to hold bureaucrats accountable. Ferry and Eckersley (2015) explain agency arrangements in the accountability required of local authorities in the United Kingdom (and the changes to those). This echoes expectations of principal-agent relationships which are experienced in central government.

Agency theory is sometimes depicted as a subset of contracting theory. Williamson (1985) interprets the contract metaphor as being either a legally binding agreement or a relational, incomplete contract (sometimes referred to as a 'social contract'). Information asymmetry between the principal and the agent/s disturbs these contracts and may be alleviated by audit. While arguably there have always been agency concerns in the public sector, the NPM of the 1980s and 1990s in many Western countries, drew inspiration from agency theory and transaction cost economics (Boston, 2011; Pallot, 2003).

Signalling: Managers of private sector companies have better information about the value and quality of their business than outside investors do ('information asymmetry'). If managers make statements in the financial report claiming that their business is a better investment than others, their claims may not be believed. Signalling is provided by engaging a higher quality auditor (or engaging an auditor voluntarily). Governments have reasons to attract investors (for example in bonds), meaning there are public sector parallels to this explanation. Other stakeholders such as voters also suffer from information asymmetry, accordingly information asymmetry may also apply more widely in the public sector (Wallace, 1987). There are studies 
(Gore, 2004) that find evidence of signalling in a local government bond market context, but no evidence at a central government level or outside the US, so that research investigating this issue at a national level is worthwhile.

Insurance: Stakeholders may demand audits to allow them to take legal action against the auditor if they need to recover investment losses (Chow 1982). Wallace (1980) suggests that an audit in the public sector can provide 'political insurance' whereby governments might use auditors to take some of the blame when there are management or accounting failures by public sector managers. Few studies examine this effect in the public sector so more research will be useful ( Green \& Singleton, 2009; Hay \& Cordery, 2018; and Ross, 1995 report incidences of the OAG being liable for losses).

Management control: Management control for the benefit of internal management is another explanation for the value of auditing. Abdel-khalik (1993) showed that private companies are more likely to choose to have an audit voluntarily when they have more layers of hierarchy. While the audit of a public sector entity is not primarily intended to provide information for the entity's top management, nevertheless the audit provides them with assurance about what is occurring in the remote corners of the entity. Hay (2003) shows that where public sector activities are more decentralised, then more use is made of accounting. Schillemans, van Twist, van der Steen et al. (2018) discuss the potential for internal audit to accomplish this in the public sector. Nevertheless, there is a lack of direct evidence about auditing and the function of management control in the public sector.

Corporate governance: Auditing can be useful as an element of corporate governance for organisations whose stakeholders are subject to higher risk. Greater emphasis on corporate governance is a feature of the NPM (Ellwood \& Garcia-Lacalle, 2016). In most studies, stronger audit committees are associated with higher quality auditors (Hay, Stewart, \& Botica Redmayne, 2017). However, there are public sector studies that show opposite results (Botica Redmayne, Bradbury, \& Cahan, 2011), implying that our study can contribute in this area.

The confirmation hypothesis: Announcements by companies, such as profit announcements, often have little impact on share prices (Ball \& Brown, 1968). As a result, the release of detailed audited financial information is sometimes regarded as less important than announcements of new, price-sensitive information. Under the confirmation hypothesis, audited announcements about past financial performance and position are important because they verify the earlier unaudited announcements (Ball, Jayaraman, \& Shivakumar, 2012). Auditing is valuable 
because it allows both unaudited and audited information to be relevant. However, with the exception of Ball et al. (Ball et al., 2012) there is no evidence as yet in either the private sector or the public sector and more investigation is needed.

In review, there is some evidence about the value of public audit, but there are also considerable gaps. Bonollo (2019) observes a need for more theorisation in research on public sector accounting. In this study, we assist in this effort by applying six mainstream explanations (discussed above) that are well-established in auditing research.

The economic explanations for the value of auditing are relevant to understanding current issues, even in settings where auditing is required by law. The explanations that we discuss explain how demand for auditing arises naturally, since there are many reasons why managers would choose auditors of their own accord. Although auditing is regulated in most settings (Bini, 2019), the economic explanations for auditing are nevertheless useful to explain why auditing has a strong position that has not been weakened by notorious auditing scandals or governmental reforms.

\section{Research context and method}

The Auditor-General of New Zealand is responsible for the financial statement audits of all public sector entities, some of which are outsourced to accounting firms. Approximately $87 \%$ of the work of the OAG is financial statement auditing on which we concentrate. The legislation defines which entities are to be audited by the Auditor-General (Buchanan \& Simpkins, 2001), and the list includes virtually all of the public sector, including for example state-owned enterprises (even where listed on the stock exchange), local councils and their subsidiaries, universities and schools. All local government entities are also audited by the OAG.

Following the request to assess the extent to which the OAG was relevant to its stakeholders, we gathered a range of qualitative and quantitative data including interviews and focus groups with OAG staff, observations and documents (see Table 2). The interview and focus group data were recorded and transcribed, with participants reviewing the transcripts before they were analysed. Staff were assured of anonymity, therefore where we quote interviewees, we use three sets of pseudonyms to indicate the area in which the staff member/s work. These are: PT (Policy Team), SM (Sector Managers) and OA (Other Areas). Individuals are identified numerically within that schema. Appropriate ethics approval for the interviews and focus groups was obtained. The OAG already collects substantial documentary evidence itself, 
including interviews with key elected representatives, public sector officials conducted by professional research companies. We also examined surveys of stakeholders in general. Further, we had available to us OAG records of news media reports on public sector auditing activities, and audit documents such as management letters. As these extensive sources were available to us, we did not carry out further collection of data from external sources.

\section{INSERT TABLE 2}

\section{Review of explanations and evidence}

Column (5) of Table 1 summarises the evidence. The relevant evidence included audit reports, other reports to Parliament, management letters, a survey of stakeholders, and reports from Parliamentary committees.

Agency: The auditor communicates with stakeholders through the audit report. Information about the number of audits is available from the Annual Report (Controller and AuditorGeneral, 2015a). We analysed a summary of the audit reports issued for the 2015/16 year, and examined the modified opinions.

There are modified audit reports that have received qualified opinions over the limited control on information from third party providers (e.g. in health). One entity received an adverse audit opinion due to not recognising museum assets and another an emphasis of matter, arising from uncertainties from the Canterbury earthquakes. In local government, 40 of 720 audit reports were modified: 3 with a disclaimer of opinion, 5 an adverse opinion and 32 qualified (Controller and Auditor-General, 2016a). Generally, these entities were small, although one of the qualified opinions was for a local authority (typically a substantial entity). Many of the same entities received modified opinions in both the 2013/4 and 2014/5 years (Controller and Auditor-General, 2015b, 2016a) and the Local Government and Environment Select Committee did not raise the issue of modifications as a matter of concern. We did not find other evidence of substantial impact from these opinions on other principals (such as citizens, voters and ratepayers), or agents (such as chief executives).

In contrast, there is evidence that Select Committees find audit reports useful. Select Committees represent Parliament and are one set of principals to whom Ministers are responsible in the agency relationship. According to The World Bank (2001, p. 2), the Westminster model of auditing includes the SAI reporting to a multiparty Public Accounts Committee which will also call other witnesses and report "to the full parliament for comment and action". In New Zealand, reports from the Auditor-General (Controller and Auditor- 
General, 2012) to Parliament are referred to the multiparty Finance and Expenditure Committee (FEC). The FEC may refer a report to another Select Committee, and OAG staff brief or advise any of these Select Committees on these reports as required. The Auditor-General (Controller and Auditor-General, 2012) attempts to raise the technical capability of Select Committees, as called for by Reichborn-Kjennerud and Johnsen (2018) and Santiso (2015). In New Zealand:

... Parliament has an induction for its new members ... [and the OAG] gave each new MP (Member of Parliament) a little pack of what they needed to know. (OA1)

As shown in table 2, we observed Select Committee meetings and examined all of the Select Committee reports which had OAG input within a twelve-month period. On one occasion an Opposition MP raised the issue of a qualified audit opinion during Parliamentary questions. The use of audit opinions, especially modified audit opinions by the Parliamentary Opposition, shows that MPs not only find OAG reports useful, but do use them. The drivers behind this use are not as apparent as the suggestions that van Helden (2016) calls for.

Select Committees raised a number of technical financial issues directly from the financial reports and audit. These included asset and liability valuation methods, audit qualifications, performance measures, and presentation issues. An OAG report on timeliness of reporting of public entities was well received, with the FEC stating it should be repeated annually. That committee also applauded the OAG report of probity in the public sector. Staff find that with the Select Committees:

...the quality of the questioning and the connection with the topic has been better than we've seen for years, which is good...there is more engagement on performance information... [and they] try and link it into a financial line... But MPs reflect society and they're not all financially literate. And so it can be quite hard for them to pick up the financials. We try to help, but it can be quite difficult. (OA1)

Agency relationships also extend to 'the people' who are reached through public reports and media communications. The media did not discuss public sector financial statement auditing very frequently. Local newspapers sometimes discussed the release of the annual report of their local council and reported the adoption by local councils of their long term plan (Daily Post, 2015; Hibiscus Matters, 2015; Waiuku \& Districts Post, 2015). News reports of councils adopting their Long Term Plan sometimes included reference to comments by Audit New Zealand staff (e.g., Rankin, 2015). 
News media are a stakeholder with an interest in reporting public information, and are also an intermediary with the public and interest groups. The OAG collects information on media coverage. We reviewed the OAG's Media Round Up documents for three selected months (July 2015, November 2015 and February 2016). These three months, spread throughout the year, were sufficient to reach convergence on the issues the media discusses. Many items were about various parties suggesting that the Auditor-General should investigate issues, or they commented on actions or reports by the Auditor-General. In 2012 the OAG commissioned a Media Opinion Audit by Busby Ramshaw Grice (2012). Busby Ramshaw Grice (2012) obtained information by interview and questionnaire from 18 media representatives. The media representatives respected the Auditor-General and her role in holding people to account (in agency terms), and viewed the OAG favourably in comparison to other 'government' organisations.

The OAG uses social media in a number of ways to reach citizens directly, and reaches substantial numbers of stakeholders. Media outlets used include Facebook, Twitter, Instagram, a blog (http://blog.oag.govt.nz/) and an email mailing list. We did not find references to financial reports or audit opinions on social media, however.

The Auditor-General also regularly makes presentations in communities:

We've said that we would consult with the public on our annual work program and this is the first year that we actually have and it - in a formal sense. So we ran a citizen panel and we had Colmar Brunton help us to run an online forum and discussion group, and we talked to them, to the people involved, members of the public who were selected from Colmar Brunton's pool, about the information theme that we plan to do for 2016/17, and asked them about their experiences with getting information and sharing ....in the public sector. (OA3)

The development of two-way relationships and consulting citizens are efforts towards moving New Zealand's OAG beyond the conventional one-way citizen relationship where citizens are only 'informed' but do not respond to the SAI (United Nations Department of Economic and Social Affairs, 2013). This can help to reduce information asymmetry.

Signalling: The choice of auditor is one way in which managers can signal that they have highquality financial reports. Under the signalling explanation, it can be predicted that when there are signals indicating higher quality financial reporting, then announcements of financial good 
news will have more impact. At the time of the 1980s reforms to the New Zealand public sector, managers of the newly-formed State-Owned Enterprises argued that they should be able to appoint audit firms who were members of the then Big 8 to give them greater credibility in financial markets (Green \& Singleton, 2009; Pallot, 2003). Their arguments were consistent with Titman and Trueman (1986) where entrepreneurs choose a more expensive, higher-quality auditor as a costly signal that shows investors that they have more favourable information.

New Zealand has a highly-regarded system of financial reporting, and auditing. Transparency International rates perceptions of public sector corruption, including administrative and political corruption. New Zealand has been ranked first equal in 2012, 2013 and 2016 (Transparency International, 2016). The use of international reviews can signal that the OAG provides quality audit. In 2008, an Australian team reviewed the OAG. The peer review found that the OAG "is a relatively small but highly regarded organisation both in New Zealand and internationally" (Barrett, 2008, p. 7).

This suggests the OAG could be seen as a high-quality auditor. Despite those advantages, which the signalling explanation predicts would make a favourable impression on investors, New Zealand does not have an unusually high credit rating compared to some other Western democracies, nor relatively low interest rates. ${ }^{2}$ The evidence from interest rates does not support the signalling explanation for auditing, but this is probably because other variables apart from auditing have a substantial influence. This lack of impact on the markets could be due to whether the financial reports are consistent with underlying good or bad news, as well as with the quality of the signalling. High interest rates in New Zealand have also been explained by the low level of saving in New Zealand (Labuschagne \& Vowles, 2010).

Private sector auditors are now usually subject to independent inspection, and public sector auditors like the $\mathrm{OAG}$ of $\mathrm{NZ}$ are an outlier in not having a statutory requirement for a periodic review. The OAG has recently arranged for the Financial Markets Authority to conduct a

\footnotetext{
${ }^{2}$ We compared the credit ratings for New Zealand and several countries of similar size or culture from Moody's (https://www.moodys.com/researchandratings/market-segment/sovereign-supranational//005005/005005\%7C042089/-/0/0/-/0/-//-/-1/-/-///en/global/pdf/-/rra), (https://www.fitchratings.com/site/sovereigns) and Standard and Poors https://www.capitaliq.com/CIQDotNet/CreditResearch/RenderArticle. aspx?articleld=2094866\&SctArtl $d=460712 \&$ from=CM\&nsI_code=LIME\&sourceObjectld=10686413\&sourceRevld=1\&fee_ind=N\&exp_ date $=20281001-19: 20: 54)$. New Zealand's credit ratings are lower than or equal to the ratings for Australia, Denmark and Norway; lower for certain credit rating agencies and higher for others compared to Finland, Ireland and the UK; and consistently higher than those of Iceland. Local media have observed that New Zealand has higher interest rates for bank deposits and mortgages than most other similar countries except for Iceland (Chaston, 2017; Gibson, 2014).
} 
quality review on the audit systems for entities that are required to lodge audited financial statements with the Registrar of Companies and that are audited by the OAG (under s. 15A of the Public Audit Act 2001). This helps to demonstrate that the OAG itself is a high-quality auditor.

The OAG also undertakes 'stakeholder engagement' (within government) which included interviews with Select Committees and senior managers of Treasury. Recommendations of particular groups are reported verbatim and ascribed to one of the 10 interviewees. Overall, the OAG is seen as being helpful in providing appropriate reports and advice. These surveys, contracted from consulting firm Touchstone, were augmented in 2014 by Martin Jenkins and Associates who surveyed 25 (named) senior public officials and select committee Chairs (Controller and Auditor-General, 2015a). Select Committee respondents were satisfied with briefings, and the OAG was seen to be "in a strong position and performing well" (Martin Jenkins and Associates, 2014, p. 15). These issues have been discussed in depth at senior management levels within the OAG and further signals that the OAG provides a quality audit.

Insurance: The insurance explanation of the demand for auditing can apply if, for example, the Auditor-General accepts responsibility for a failure in management control over expenditure. This could provide either recovery of financial losses or the 'political insurance' suggested by (Wallace, 1980). There have been cases where legal action for monetary losses has been brought against the Auditor-General of New Zealand in 1949 and in the 1980s (Green and Singleton, 2009, pp. 82 and 145). There is a recent case where the OAG accepted responsibility, the case of Kaipara District Council. According to Radio New Zealand News (2013), Auditor-General Lyn Provost said: "an independent reviewer identified problems with some of the audit work carried out by Audit New Zealand. For that, I apologise unreservedly to each and every one of you." The Kaipara District Council subsequently took legal action against the Auditor-General, so that both financial and political insurance were evident, making the insurance explanation even more salient (Ali, 2015).

Management control: One aspect of the audit function in relation to management control is through assessing internal control and providing recommendations to management, through management letters. The recommendations provide value to a range of stakeholders including management of the entity, those charged with governance, Parliament and possibly wider groups of stakeholders. The recommendations made each year are summarised in the annual report of the OAG (Illustration 1) (Controller and Auditor-General, 2015a). The information 
that the OAG uses to prepare the chart in Illustration 1 is drawn from a sample of 45 management letters for a broad selection of larger entities. We examined those letters.

\section{INSERT ILLUSTRATION 1}

Illustration 1 shows that the OAG reported on 194 recommendations made in 45 management letters, of which 138 (71\%) were accepted, 39 noted, 7 rejected and 10 not responded to (Office of the Auditor-General, 2016a). We found from reviewing the letters that sometimes, although management accepted a recommendation, the problem was not resolved, and the issue was still outstanding the following year. One large local authority had six weaknesses in this category. We also observed entities with large numbers of weaknesses (as many as 23). OAG briefings reported that the management control environment of some entities' financial information system and controls "need improvement". In at least one case, this situation recurred from the previous year. Internationally, the measurement of accepted recommendations has ranged from $21 \%$ (Raudla, Taro, Agu, \& Douglas, 2015) but are more typically in the $70-90 \%$ range (Azuma, 2004; Lonsdale, 2000). Requiring reporting of the number of recommendations remediated by the time of the next audit and highlighting those not remediated, would provide a stronger measure of whether management takes action on recommendations. It would highlight the state of internal control in the New Zealand public sector. Bedard \& Graham (2014) argue that while reporting on internal control in the United States was initially unwelcome, it has had benefits. They suggest that "not far behind is the potential requirement that governments publicly report on the effectiveness of their controls as a part of their stewardship of public monies" (Bedard \& Graham, 2014). No internal control reporting is required in the New Zealand public sector, but this offers a potential value adding activity.

Further, the OAG assesses satisfaction of auditees (Controller and Auditor-General, 2015a). It undertakes extensive surveys of audit clients, obtaining specific feedback on aspects of the audit, auditors' skills, knowledge and so on. These are reported by service provider and by subsector. The 2015 Colmar Brunton (Institute for Governance and Policy Studies, 2016) survey shows satisfaction by audit clients is high $-87 \%-$ a $2 \%$ increase on the prior year. The OAG has a wealth of information to encourage audit service providers, both internal and outsourced, to improve in deficient areas.

Corporate governance: The OAG examined corporate governance in the New Zealand public sector in a recent report (Controller and Auditor-General, 2016b). The Auditor-General 
commented: "In my opinion, the quality of governance in the public sector can be improved. It is not working as well as it should in some entities and problems have occurred and will continue to do so, unless the standard is raised" (Controller and Auditor-General, 2016b, p. 3). Accordingly:

... one of the things we have been doing and pushing really hard is audit and risk committees in local government ... When they have a 'new mayors' school' ... what we did there was push very hard, "you should set up an audit and risk committee" and we have said, "you should have independent members on it, because that's a way to get the financial expertise to ask the right questions, into the system". (OA1)

Our research found entities which have audit committees, but do not mention them in annual reports or websites. Fama and Jensen (1983) and Srinivasan (2005) argue that part of making independent directors effective is in putting their personal reputation as experts at risk. Therefore we found it surprising that public sector entities were not encouraged to disclose the membership and activities of their audit committees.

Confirmation: Under the confirmation hypothesis, audits retain importance even when unaudited information is widely used. This is because the audited financial statements provide confirmation of earlier announcements (Ball et al., 2012). This explanation could be highly relevant for the public sector, although citizens in their capacity as taxpayers and ratepayers are unlikely to consult audited financial statements. Nevertheless, they obtain information from sources such as the media or announcements by public sector entities, and they probably assume that this information is reliable. It might be useful for auditors to consider what unaudited announcements are made, and consider whether they are consistent with the audited financial statements that are later released.

We discussed this issue in focus groups, when staff assumed that data from, for example, local authorities' summary statements to ratepayers, would be derived from audited financial statements, but that:

If you think about the stakeholders ... what information do they rely on to know that these entities are performing and not diddling them and generally behaving? It's mostly non-audited information isn't it? It's statements from politicians, it's unaudited pamphlets and things from their local authorities. It's Official Information 
inquiries from journalists. It's those sort of things. It's not audited information that they directly rely on. (PT 3)

An example of an unaudited announcement that stakeholders might rely on includes announcements by local governments about how much their rates (property taxes) are and what they are used for. Illustration 2 provides a recent example from Auckland Council.

\section{INSERT ILLUSTRATION 2}

In the public sector, unlike the financial market examples that Ball et al. (2012) were referring to, there are unlikely to be analysts who would draw attention to any discrepancy between earlier announcements and audited results. It could be a valuable part of public auditing to check such announcements against audited financial statements.

\section{Limitations}

Although external documents were used in this research, external parties were not interviewed. This is due to the extensive evidence already available from the surveys and interviews conducted by or on behalf of the OAG, and the existence of survey fatigue among potential respondents. Many of the documents that we examined obtained data from external sources including a wide range of stakeholders. Further, the data is a case study from one country only. Nevertheless, as New Zealand is considered to be at the forefront of public sector auditing, this data provides an example that can be benchmarked and discussed in other jurisdictions that have similar public sector audit institutions.

\section{Discussion and Conclusions}

The objective of our study was to examine the application of explanations for the value of private sector auditing in the New Zealand public sector, to highlight possible explanations that could be used in public audit studies in light of the dichotomy between private sector and public sector auditing research. We therefore examined six explanations for the value of auditing that have been found useful in private sector research. We found that some, but not all private sector audit explanations were valuable in explaining the value of public audit to stakeholders in demonstrating the SAI's ongoing relevance. Further, our study also shows how complex public audit work is as reporting practices must be varied and private sector explanations must be put in context. The results are relevant to the needs of the SAI and led to the following findings and recommendations. 
This research has analysed the value of financial statement auditing in the public sector, finding that many of the benefits of audit that are supported by research in the private sector are evident also in the public sector. Previous research has explored these explanations to a limited extent, but has not demonstrated the application of each of the explanations, some of which show that public sector audit is valuable to a variety of stakeholders in different ways.

Agency theory has previously been a useful explanation for public sector auditing, but environmental changes render other explanations useful as well, and there is now increasing evidence about the ways in which they are useful. Yet, different stakeholders will perceive the value of auditing in different ways. For some stakeholders, the value will arise from agency issues, for others from signalling or management control, for others corporate governance. Signalling could also occur, because the OAG can be shown to be a high-quality auditor, although we did not find evidence of economic benefits from this mechanism. Stakeholders will see insurance benefits from an audit infrequently, but this will nevertheless occur in some cases. There is evidence of increasing benefits from audits in helping management to identify potential improvements in control, and in contributing to improved governance. We find less evidence of the confirmation hypothesis being useful.

Nevertheless, one or more of the theoretical models for the value of public audit is found to be helpful in explaining the value to each set of stakeholders. The willingness of Opposition Members of Parliament to challenge public sector entities as a result of the auditors' work is one example of a growing familiarity with financial and non-financial reporting and a stronger focus on agency arrangements. Further, increased reporting on issues raised in management letters and recommendations (and the attention to these), suggest that management control may be a growing area in which audit can be useful to stakeholders and relevant changes may be cost-neutral. The confirmation hypotheses was less likely to be a reason for public audit to have value as media has less interest in investigative journalism (Walton, 2010). However, the rise of "armchair auditors" (O’Leary, 2015) could see citizens demanding more accountability for unaudited results. Overall, this study adds to our evidence about the relevance of these six theoretical views of the value of auditing, by demonstrating public sector relevance but also recognising the unique context. Accordingly, the public sector provides rich sources for further research.

The OAG utilises extensive sources of feedback on the perceptions of stakeholders. These included surveys of stakeholders, media viewpoints on the OAG, and analysis of news reports 
and social media. In addition, the added inspection by the Financial Markets Authority will provide feedback similar to that which private sector auditors receive. Arguably, the OAG (and possibly other SAIs) are in a better position to provide value to stakeholders because of these additional feedback sources. However, a wider range of stakeholders is involved (as discussed in the quotation earlier from Moe, 1984) and it is likely that the benefits or harm caused by public audit will have a greater impact than a private sector audit. For this reason, the OAG reports not only to Parliament, but also publicly, is open about stakeholder feedback on its services and strives to improve public sector accountability through its activities and influence. In general, we were able to conclude that the OAG can demonstrate value to shareholders in many ways (as required under ISSAI 12).

We also suggested practices that could be extended to enhance the value of public audit in New Zealand and potentially, elsewhere. The recommendations are, first, that public sector audit bodies should be independently inspected, as private sector auditors now are. Second, requiring auditees to report on internal control weaknesses will be valuable. There should be more disclosure about the membership and activities of audit committees. Finally, auditors should be more aware of the extent to which unaudited information is relied on by stakeholders, and to what extent it is confirmed by subsequent audited information.

Further research opportunities are widespread in this area of research. These include greater documentation of public sector auditing in a wider range of countries, and more comparison between them, so that it becomes clearer how a variety of SAIs provide value to their stakeholders, and why variations exist. This examination could also extend into historic reasons for differences, and whether particular historic events or crises have influenced public audit in each country. More development of quantitative comparative studies (Blume \& Voigt, 2011) that are further developed to take into account what is known about select committees, the role of the media and other aspects discussed above would be useful. There will be continuing opportunities for development due to continuing changes in the environment such as changing media interest, declining public use of published public sector accounting information, but increasing availability and use of online data. The challenge is for SAIs to be alert to the different reasons that stakeholders may demand audit in this unique context and to provide evidence of how they do this in a way that recognises how their needs differ from those of private sector stakeholders. The imperative to deliver value should continue to underpin the activities of SAIs as they seek to make a difference to the lives of citizens. 
References

Abdel-khalik, A. R. (1993). Why Do Private Companies Demand Auditing? A Case for Organizational Loss of Control. Journal of Accounting, Auditing \& Finance, 8(1), 3152. https://doi.org/10.1177/0148558X9300800103

Ali, I. (2015). Legal action over "botched" scheme. Northern Advocate. Retrieved from http://www.nzherald.co.nz/northernadvocate/news/article.cfm?c_id=1503450\&objectid=11387306

Azuma, N. (2004). Performance Measurement of Supreme Audit Institutions in 4 AngloSaxon Countries : Leading by Example. Government Auditing Review, 11(March), 6599.

Baber, W. R. (1983). Toward understanding the role of auditing in the public sector. Journal of Accounting and Economics, 5(C), 213-227. https://doi.org/10.1016/01654101(83)90013-7

Ball, R., \& Brown, P. (1968). An Empirical Evaluation of Accounting Income Numbers. Journal of Accounting Research, 6(2), 159-178. Retrieved from http://www.jstor.org/stable/2490232

Ball, R., Jayaraman, S., \& Shivakumar, L. (2012). Audited financial reporting and voluntary disclosure as complements: A test of the Confirmation Hypothesis. Journal of Accounting and Economics, 53(1-2), 136-166. https://doi.org/10.1016/j.jacceco.2011.11.005

Barrett, P. (2008). Report on the Efficiency and Effectiveness of the Office of the Controller and Auditor-General of New Zealand by an International Peer Review Team.

Barrett, P. (2012). Performance auditing — addressing real or perceived expectation gaps in the public sector. Public Money \& Management, 32(2), 129-136. https://doi.org/10.1080/09540962.2012.656019

Bedard, J. C., \& Graham, L. (2014). Reporting on internal control. In D. Hay, R. Knechel, \& M. Willekens (Eds.), The Routledge Companion to Auditing (pp. 311-322). Abingdon, UK: Routldege.

Bini, M. (2019). Models of mandate in public audit: An examination of Australian jurisdictions. Public Money and Management, 39(3), 201-208. https://doi.org/10.1080/09540962.2018.1535028

Blume, L., \& Voigt, S. (2011). Does organizational design of supreme audit institutions 
matter? A cross-country assessment. European Journal of Political Economy, 27(2), 215-229. https://doi.org/10.1016/j.ejpoleco.2010.07.001

Bonollo, E. (2019). Measuring supreme audit institutions' outcomes: current literature and future insights. Public Money \& Management, O(0), 1-10. https://doi.org/10.1080/09540962.2019.1583887

Boston, J. (2011). Basic NPM Ideas and their Development. In T. Christensen \& P. Lægreid (Eds.), The Ashgate research companion to new public management (pp. 35-50). Ebooks Corporation.

Botica Redmayne, N., Bradbury, M. E., \& Cahan, S. F. (2011). The Association between Audit Committees and Audit Fees in the Public Sector. International Journal of Auditing, 15(3), 301-315. https://doi.org/10.1111/j.1099-1123.2011.00436.x

Bradbury, M. E., \& Scott, T. (2015). The association between accounting performance and constituent response in political markets. Pacific Accounting Review, 27(4), 394-410. https://doi.org/10.1108/PAR-02-2014-0007

Buchanan, R., \& Simpkins, K. (2001). A New Age for Public Auditing. Chartered Accountants Journal of New Zealand, (July), 8-11.

Busby Ramshaw Grice. (2012). Office of the Auditor-General Media Opinion Audit, A baseline study. Wellington, New Zealand.

Chaston, D. (2017). We look at how New Zealand mortgage pricing compares. Retrieved October 30, 2018, from https://www.interest.co.nz/news/90842/we-look-how-newzealand-mortgage-pricing-compares-what-aussies-pay-same-sort-loans-we

Chow, C. W. (1982). The demand for external auditing:size, debt and ownership influences. The Accounting Review, 57(2), 272-291.

Controller and Auditor-General. (2012). MPs' guide to the Auditor-General. Wellington, New Zealand.

Controller and Auditor-General. (2015a). Annual Report 2014/15. Wellington, NZ: Office of the Auditor-General.

Controller and Auditor-General. (2015b). Local government: Results of the 2013/14 audits. Retrieved from www.oag.govt.nz

Controller and Auditor-General. (2016a). Local government: Results of the 2014/15 audits. Wellington, New Zealand.

Controller and Auditor-General. (2016b). Reflections from our audits: Governance and Accountability.

Daily Post. (2015, July 1). 10-year plan adopted in principle. Daily Post. 
Ellwood, S., \& Garcia-Lacalle, J. (2016). Examining Audit Committees in the Corporate Governance of Public Bodies. Public Management Review, 18(8), 1138-1162. https://doi.org/10.1080/14719037.2015.1088566

Fama, E. F., \& Jensen, M. C. (1983). Agency Problems and Residual Claims. The Journal of Law and Economics, 26(2), 327-349. https://doi.org/10.1086/467038

Ferry, L., \& Eckersley, P. (2015). Budgeting and governing for deficit reduction in the UK public sector: act three 'accountability and audit arrangements.' Public Money \& Management, 35(3), 203-210. https://doi.org/10.1080/09540962.2015.1027496

Gibson, A. (2014, October 18). NZ mortgage rates: How we compare with rest of the world. New Zealand Herald. Retrieved from http://www.nzherald.co.nz/nz/news/article.cfm?c_id=1\&objectid=11344401

Goddard, A. (2010). Contemporary public sector accounting research - An international comparison of journal papers. The British Accounting Review, 42(2), 75-87. https://doi.org/10.1016/j.bar.2010.02.006

Gore, A. K. (2004). The effects of GAAP regulation and bond market interaction on local government disclosure. Journal of Accounting and Public Policy, 23(1), $23-52$. https://doi.org/10.1016/j.jaccpubpol.2003.11.002

Green, D., \& Singleton, J. (2009). The Watchdog: New Zealand's Audit Office from 1840 to 2008. Dunedin, New Zealand: Otago University Press.

Grossi, G., Newberry, S., Bergmann, A., Bietenhader, D., Tagesson, T., Christiaens, J., ... Rommel, J. (2009). Theme: Whole of government accounting — international trends. Public Money \& Management, 29(4), 209-218. https://doi.org/10.1080/09540960903034968

Hay, D. C. (2003). Knowledge transfer costs and dependence as determinants of financial reporting. Accounting and Finance, 43(3), 311-330. https://doi.org/10.1111/j.1467629x.2003.00093.x

Hay, D. C., Stewart, J., \& Botica Redmayne, N. (2017). The Role of Auditing in Corporate Governance in Australia and New Zealand: A Research Synthesis. Australian Accounting Review, 27(4), 457-479. https://doi.org/10.1111/auar.12190

Hay, D., \& Cordery, C. (2018). The value of public sector audit: Literature and history. Journal of Accounting Literature, 40, 1-15. https://doi.org/10.1016/j.acclit.2017.11.001 Hibiscus Matters. (2015, July 1). Councillors clash with Local Board over transport targeted rate. Hibiscus Matters.

Ingram, R. W. (1984). Economic Incentives and the Choice of State Government Accounting 
Practices. Journal of Accounting Research, 22(1), 126-144.

https://doi.org/10.2307/2490704

Institute for Governance and Policy Studies. (2016). Who Do We Trust? Wellington, NZ. International Organization of Supreme Audit Institutions. (2013). ISSAI 12: The Value and Benefits of Supreme Audit Institutions - making a difference to the lives of citizens, 113.

Jensen, K. L., \& Payne, J. L. (2005). Audit Procurement: Managing Audit Quality and Audit Fees in Response to Agency Costs. Auditing: A Journal of Practice \& Theory, 24(2), 27-48. https://doi.org/10.2308/aud.2005.24.2.27

Labuschagne, N., \& Vowles, P. (2010). Why are Real Interest Rates in New Zealand so High? Evidence and Drivers (No. 10/09). Wellington. Retrieved from http://www.treasury.govt.nz/publications/research-policy/wp/2010/10-09

Lonsdale, J. (2000). Developments in Value-For-Money Audit Methods: Impacts and Implications. International Review of Administrative Sciences, 66(1), 73-89. https://doi.org/10.1177/0020852300661007

Martin Jenkins and Associates. (2014). Office of the Auditor-General Stakeholder survey results 2014 Confidential report.

Moe, T. M. (1984). The New Economics of Organization. American Journal of Political Science, 28(4), 739-777.

Office of the Auditor-General. (2016). Annual Review briefing to the Law \& Order Committee: New Zealand Police. Wellington, NZ.

Pallot, J. (2003). A Wider Accountability? The Audit Office and New Zealand's Bureaucratic Revolution. Critical Perspectives on Accounting, 14(1-2), 133-155. https://doi.org/10.1006/cpac.2001.0518

Radio New Zealand News. (2013). Auditor-General apologises to Kaipara ratepayers. Radio New Zealand. Retrieved from http://www.radionz.co.nz/news/national/229668/auditorgeneral-apologises-to-kaipara-ratepayers

Rankin, J. (2015, June 30). Regional rates relief for flood victims. Manawatu Standard. Retrieved from http://www.stuff.co.nz/manawatu-standard/news/69835451/Regionalrates-relief-for-floodvictims

Raudla, R., Taro, K., Agu, C., \& Douglas, J. W. (2015). The Impact of Performance Audit on Public Sector Organizations: The Case of Estonia. Public Organization Review, in press, 17. https://doi.org/10.1007/s11115-015-0308-0

Reichborn-Kjennerud, K., \& Johnsen, Å. (2018). Performance Audits and Supreme Audit 
Institutions' Impact on Public Administration: The Case of the Office of the Auditor General in Norway. Administration \& Society, 50(10), 1422-1446.

https://doi.org/10.1177/0095399715623315

Ross, M. (1995). Audit negligence. Chartered Accountants Journal, (April), 56-57.

Santiso, C. (2015). Why budget accountability fails? The elusive links between Parliaments and audit agencies in the oversight of the budget. Brazilian Journal of Political Economy, 35(3(140)), 601-621.

Schillemans, T., van Twist, M., van der Steen, M., \& de Jong, I. (2018). New development: Breaking out or hanging on? Internal audit in government. Public Money and Management, 38(7), 531-534. https://doi.org/10.1080/09540962.2018.1527574

Srinivasan, S. (2005). Consequences of Financial Reporting Failure for Outside Directors: Evidence from Accounting Restatements and Audit Committee Members. Journal of Accounting Research, 43(2), 291-334. https://doi.org/10.1111/j.1475679x.2005.00172.x

Streim, H. (1994). Agency problems in the legal political system and supreme auditing institutions. European Journal of Law and Economics, 1(3), 177-191. https://doi.org/10.1007/BF01552469

Talbot, C., \& Wiggan, J. (2010). The public value of the National Audit Office. International Journal of Public Sector Management, 23(1), 54-70. https://doi.org/10.1108/09513551011012321

Titman, S., \& Trueman, B. (1986). Information quality and the valuation of new issues. Journal of Accounting and Economics, 8, 159-172.

Transparency International. (2016). Corruption Perceptions Index. Retrieved January 31, 2017, from http://www.transparency.org/news/feature/corruption_perceptions_index_2016

United Nations Department of Economic and Social Affairs. (2013). Citizen Engagement Practices by Supreme Audit Institutions Citizen Engagement Practices by Supreme Audit Institutions. New York NY.: United Nations.

van Helden, J. (2016). Literature review and challenging research agenda on politicians' use of accounting information. Public Money \& Management, 36(7), 531-538. https://doi.org/10.1080/09540962.2016.1237162

Waiuku \& Districts Post. (2015, June 30). Franklin Ward councillor voted “yes.” Waiuku \& Districts Post.

Wallace, W. A. (1980). The Economic Role of The Audit in Free and Regulated Markets. 
New York NY.: Touche Ross Foundation. Retrieved from

https://trove.nla.gov.au/work/18348960?selectedversion=NBD3508249

Wallace, W. A. (1987). The Economic Role of the Audit in Free and Regulated Markets. Advances in Accounting, 1, 7-34.

Williamson, O. (1985). The Economic Institutions of Capitalism: Firms, Markets, Relational Contracting. New York: Free Press.

World Bank, T. (2001). Features and functions of supreme audit institutions. from the Development Economics Vice Presidency and Poverty Reduction and Economic Management Network.

Zimmerman, J. L. (1977). The Municipal Accounting Maze: An Analysis of Political Incentives. Journal of Accounting Research, 15, 107. https://doi.org/10.2307/2490636 
Table 1: Summary of evidence and explanations for the value of public audit

\begin{tabular}{|c|c|c|c|c|}
\hline $\begin{array}{l}\text { Explanations } \\
\text { (1) }\end{array}$ & $\begin{array}{l}\text { Private sector } \\
\text { explanations (2) }\end{array}$ & $\begin{array}{l}\text { Public sector } \\
\text { application (3) }\end{array}$ & $\begin{array}{l}\text { Gaps in public sector } \\
\text { evidence based on } \\
\text { previous research (4) }\end{array}$ & Evidence from this study (5) \\
\hline Agency & $\begin{array}{l}\text { Agency relationships, } \\
\text { agency costs are } \\
\text { ameliorated by audit }\end{array}$ & $\begin{array}{l}\text { Municipal structure; } \\
\text { SAI and economic } \\
\text { performance }\end{array}$ & $\begin{array}{l}\text { Limited evidence of } \\
\text { audit being used to } \\
\text { reduce agency costs }\end{array}$ & $\begin{array}{l}\text { Audit reports (some modified); reports to } \\
\text { Parliament and Parliamentary committees; } \\
\text { media and public attention (limited) }\end{array}$ \\
\hline Signalling & $\begin{array}{l}\text { Signalling of high quality } \\
\text { audit should reduce costs } \\
\text { of borrowing/ equity }\end{array}$ & $\begin{array}{l}\text { Auditing is a useful } \\
\text { signal in the bond } \\
\text { market }\end{array}$ & $\begin{array}{l}\text { Not much evidence of } \\
\text { signalling for central } \\
\text { government and non- } \\
\text { US entities }\end{array}$ & $\begin{array}{l}\text { Audit reports } \\
\text { High quality audit (surveys, assessments, } \\
\text { standards), high interest rates in New } \\
\text { Zealand }\end{array}$ \\
\hline Insurance & $\begin{array}{l}\text { Auditor has 'deep } \\
\text { pockets'. Stake-holders } \\
\text { may be able to recover } \\
\text { losses }\end{array}$ & $\begin{array}{l}\text { 'Reputation } \\
\text { insurance' }\end{array}$ & $\begin{array}{l}\text { Limited evidence of } \\
\text { role of audit in } \\
\text { providing insurance for } \\
\text { stakeholders }\end{array}$ & $\begin{array}{l}\text { Auditor providing reputation and financial } \\
\text { insurance }\end{array}$ \\
\hline $\begin{array}{l}\text { Corporate } \\
\text { Governance }\end{array}$ & $\begin{array}{l}\text { Governance and audit are } \\
\text { complementary to reduce } \\
\text { risk }\end{array}$ & $\begin{array}{l}\text { Governance and audit } \\
\text { are substitutes to } \\
\text { reduce risk }\end{array}$ & $\begin{array}{l}\text { Opposite results to } \\
\text { private sector }\end{array}$ & Audit committees; performance audits \\
\hline Confirmation & $\begin{array}{l}\text { Unaudited announcements } \\
\text { are confirmed by audit }\end{array}$ & --- (not studied) & No evidence as yet & $\begin{array}{l}\text { Unaudited announcements; absence of } \\
\text { evidence about confirmation }\end{array}$ \\
\hline
\end{tabular}


Table 2: Data collected for study

\begin{tabular}{|c|c|c|}
\hline Data collected from & Content/topic of data & Participants/Source \\
\hline Interviews $^{3}$ & \multirow{2}{*}{$\begin{array}{l}\text { Stakeholders of audit, their demands and how these are } \\
\text { met }\end{array}$} & OAG staff \\
\hline Focus Groups & & OAG staff teams \\
\hline $\begin{array}{l}\text { Attendance at public hearing } \\
\text { of select committee }(3 / 3 / 16)\end{array}$ & $\begin{array}{l}\text { Post-audit review of 2014/2015 Annual Reviews of two } \\
\text { State-owned Enterprises: Meteorological Service of } \\
\text { New Zealand Limited and the Public Trust }\end{array}$ & $\begin{array}{l}\text { Relevant Members of Parliament, supporting staff, } \\
\text { SOE staff }\end{array}$ \\
\hline $\begin{array}{l}\text { Select Committee reports on } \\
\text { entities (between } 15 / 5 / 15 \text { - } \\
14 / 5 / 16 \text { ) }\end{array}$ & $\begin{array}{l}\text { Reports on performance of public sector entities on } \\
\text { which the OAG had input (including through audit } \\
\text { reports, reports on annual reviews and vote estimates, } \\
\text { performance reports, and verbal advice }\end{array}$ & $\begin{array}{l}162 \text { Publically available reports by } 14 \text { different Select } \\
\text { Committees * }\end{array}$ \\
\hline OAG's Media Round Up & $\begin{array}{l}\text { New items that discuss public sector reporting and the } \\
\text { OAG }\end{array}$ & July 2015, November 2015, February 2016. \\
\hline Management letters & $\begin{array}{l}\text { Letters from OAG to entities post-audit including key } \\
\text { audit matters and recommendations. }{ }^{* *}\end{array}$ & $\begin{array}{l}\text { A sample of } 45 \text { management letters for a broad } \\
\text { selection of larger entities }\end{array}$ \\
\hline
\end{tabular}

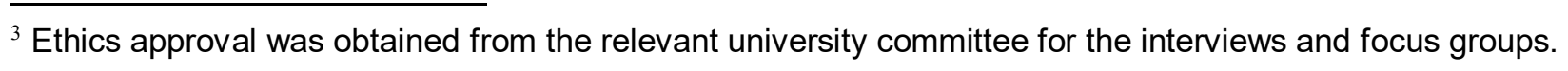




\begin{tabular}{|c|c|c|}
\hline Data collected from & Content/topic of data & Participants/Source \\
\hline $\begin{array}{l}\text { Social media (posts between } \\
15 / 5 / 15-14 / 5 / 16)\end{array}$ & $\begin{array}{l}\text { Engagement with public on matters of relevance to the } \\
\text { OAG (These did not include references to financial } \\
\text { reports or audit opinions) }\end{array}$ & Facebook posts, Twitter, Instagram, Blog*** \\
\hline $\begin{array}{l}\text { Surveys of perceptions of } \\
\text { public sector audit** }\end{array}$ & $\begin{array}{l}\text { 1. Perceptions of } 10 \text { interviewees (Select } \\
\text { Committees, their Chairs and Treasury senior staff) } \\
\text { 2. Perceptions of } 25 \text { named interviewees (senior } \\
\text { public officials and select committee Chairs) } \\
\text { 3. Surveys of audit clients }\end{array}$ & $\begin{array}{l}\text { 1. Touchstone (in } 2012 \text { and 2013) } \\
\text { 2. Martin Jenkins Associates (in 2014) } \\
\text { 3. OAG (2016 sighted) }\end{array}$ \\
\hline $\begin{array}{l}\text { OAG Annual reports and } \\
\text { Annual Plan }\end{array}$ & Financial data and summaries of audit activity & $\begin{array}{l}\text { Annual Reports for years ending } 30 \text { June 2011-2015 } \\
\text { Annual plan for 2015/16. }\end{array}$ \\
\hline OAG Auditing Standards & $\begin{array}{l}\text { Include all International Audit Standards plus } \\
\text { additional requirements/ commentary on public sector } \\
\text { issues }\end{array}$ & Version current as at 30 June 2016. \\
\hline
\end{tabular}

* Data was downloaded from: http://www.parliament.nz/en-nz/pb/sc/documents

*** These are internal documents to the OAG which were provided to the researchers in confidence.

** See http://blog.oag.govt.nz/ 
Output class: Audit and assurance services

2014/15 results and previous performance for Audit and assurance services

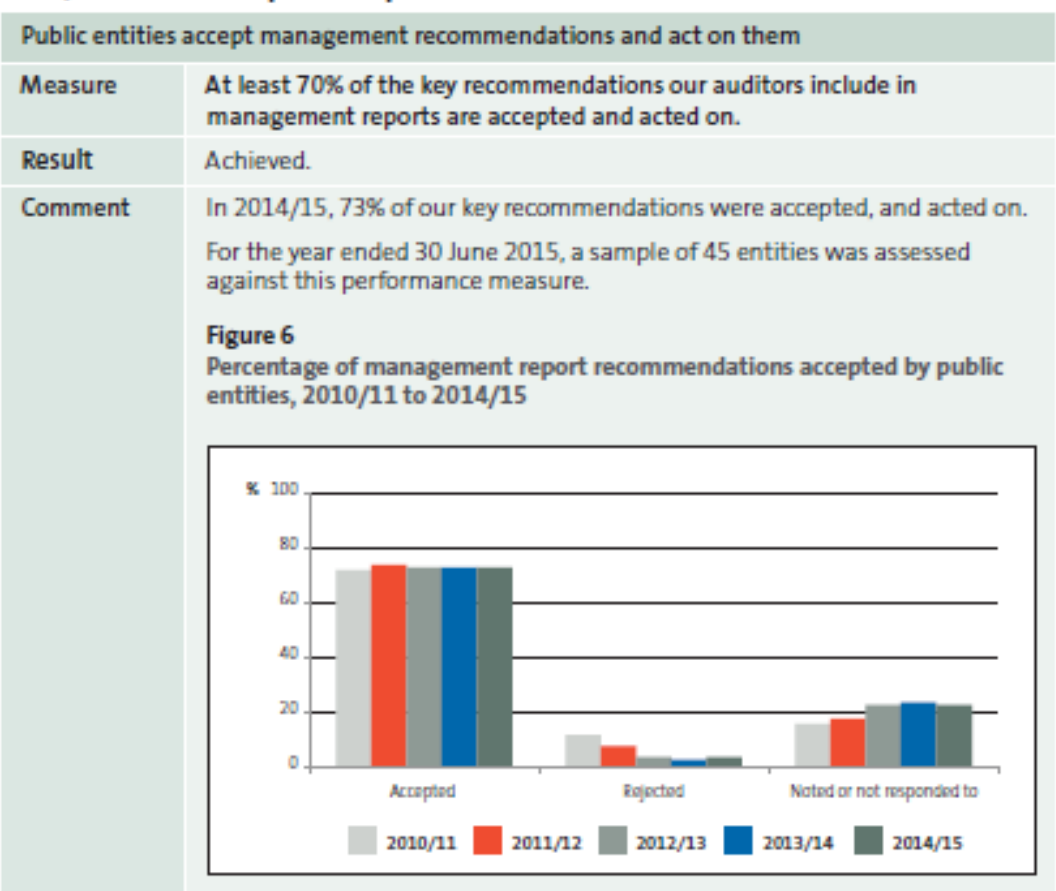

Illustration 1: The OAG reporting on management report recommendations (from the 2015 OAG annual report) 


\section{Rates spend per $\$ 100$}

Rates provide approximately 45 per cent of the council's revenue with the rest coming from grants, subsidies, development and financial contributions, user charges and fees.

Each $\$ 100$ of general rates funding is applied to specific themes. The largest proportion of rates funding is used to fund the transport theme, followed by lifestyle and culture, which includes funding for events, parks, recreation and art services View the doughnut chart showing portion of $\$ 100$ spent on each theme below, click to see larger image.

Transport, $\$ 36$

Including buses, trains and ferries, roads, footpaths and cycleways, key infrastructure projects, safety and education.

Parks, Community and Lifestyle, \$26 Including parks and open spaces, aquatic and recreation facilities, community centres and libraries, public art, community services and local events.

Environmental Management and Regulation, \$16

Including stormwater management, consent processing, licensing and compliance services, rubbish and recycling services, emergency management and environmental programmes.

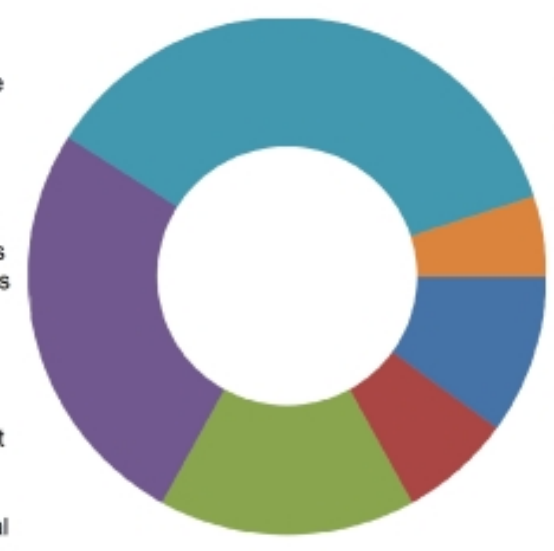

Governance and Support, \$5 Including elections, support for elected members and the Independent Maori Statutory Board, management of council property and investments, funding of external regional museums and amenities

Auckland Development, $\$ 10$ Including planning and strategy, city centre and waterfront development, local area economic improvement and town centre redevelopment.

Economic and Cultural Development, \$7 Including supporting economic growth and the visitor economy, major events, regional arts and sports venues, Auckland Art Gallery and Auckland Zoo.

Illustration 2: from the Auckland Council website

\section{Downloaded from}

http://www.aucklandcouncil.govt.nz/EN/ratesbuildingproperty/ratesvaluations/billingpaymen t/Pages/howyourratesarespent.aspx 17 May 2016 